\title{
Isabelle Attané et C. Z. Guilmoto (éd.), Watering the Neighbours' Garden. The Growing Demographic Deficit in Asia.
}

\section{Cecilia Milwertz}

\section{(2) OpenEdition}

\section{Journals}

Electronic version

URL: http://journals.openedition.org/chinaperspectives/3953

DOI: 10.4000/chinaperspectives.3953

ISSN: 1996-4617

\section{Publisher}

Centre d'étude français sur la Chine contemporaine

\section{Printed version}

Date of publication: 4 April 2008

Number of pages: 117-118

ISSN: 2070-3449

\section{Electronic reference}

Cecilia Milwertz, «Isabelle Attané et C. Z. Guilmoto (éd.), Watering the Neighbours' Garden. The Growing Demographic Deficit in Asia. », China Perspectives [Online], 2008/2 | 2008, Online since 01 April 2008, connection on 24 September 2020. URL : http://journals.openedition.org/ chinaperspectives/3953; DOI : https://doi.org/10.4000/chinaperspectives.3953

This text was automatically generated on 24 September 2020 .

(c) All rights reserved 


\title{
Isabelle Attané et C. Z. Guilmoto (éd.), Watering the Neighbours' Garden. The Growing Demographic Deficit in Asia.
}

\author{
Cecilia Milwertz
}

1 The phrase "watering the neighbour's garden" refers to wasting valuable resources on something that will not benefit oneself. This book addresses "the rampant demographic masculinisation" or "gender cleansing" in Asia. These two terms are used to define the phenomenon of increasing the numbers of boys and men relative to girls and women. In their introduction to the book, editors Attané and Guilmoto note that whereas neglect of infant girls, generally related to poverty, was previously a main cause of skewed sex ratios among infants, more recently new technologies have enabled sexselective abortion among the middle and upper classes. The premise of the book is that social science research has not sufficiently addressed the significant problem of rigorous sex discrimination against girls, and the resultant skewed sex ratios. The editors contrast the relative lack of attention accorded to Asia's estimated 100 million "missing" females - female babies that were never born and girls and women who died early - with international concern over AIDS-related deaths, which have affected one quarter of that number - 25 million - worldwide. The aim of the book is to focus attention on the hugely understudied issue of skewed sex ratios in a series of chapters that present studies of causes, consequences, practices, and meanings of the phenomenon, and the ways in which it is addressed, or indeed, not addressed. The majority of the chapters (12 out of 17) deal with the People's Republic of China and/or India, the two countries responsible for the largest numbers of missing girls and women. One of the China chapters focuses on trans-national migration, marriage, and trafficking at the China-Vietnam border. Also included are chapters on Singapore, Bangladesh, and South Korea, a chapter on marriage migration from Vietnam to Taiwan, and a chapter on three countries in the Caucasus region - Azerbaidjan, Georgia, and Armenia. 
2 Unbalanced sex ratios are, as the editors note in their introduction, a blatant symptom of intense discrimination against girls and women. In the book's first chapter, Li Shuzhuo, Wei Yan, Jiang Quanbao, and Marcus W. Feldman start with the assertion that the phenomenon of missing girls "not only violates the rights of survival, participation and development for girl children, but also produces dangerously imbalanced sex ratios and concomitant demographic and social problems that threaten the long term stability and sustainable development of Chinese society" (p. 25). This ethical and political position is echoed throughout the book and underlies the call for an increased research focus on the issue. However, this position cannot be taken for granted, and the arguments in the book would stand stronger if this basic premise had been made as an argument rather than as a statement. As the editors point out in their introduction, the issue of the right to abortion in relation to the issue of sex-selective abortion is highly sensitive ethically and politically. Nonetheless, the book would have benefited from more in-depth discussion and analysis of such issues. How can we, for example, consider it unacceptable to abort a foetus because it is female, while the abortion of a nonsex- defined foetus is (at least for some) acceptable based on the view that the pregnant woman has the right to self-determination?

3 The book is divided into four main thematic sections: I) Recent trends in sex ratio in Asia, II) Differentials in discriminatory behaviour, III) Local perspectives on gender bias and, IV) Policy response and impact. The chapters do not necessarily fit neatly into these categories. Several tend rather to cut across the themes with, for instance, chapters in parts I, II and III addressing policy issues. More importantly, however, the book provides valuable and nuanced insights into many different aspects of a huge and complex issue. As space does not allow for comments on all chapters, the following are a few examples of the variety of issues covered.

4 The chapter by Le Bach Duong, Danièle Bélanger, and Khuat Thu Hong on migration and trafficking from Vietnam to China is concerned with the paradoxical situation under which a deficit of women in China has provided new opportunities for migration and improved lives for women from Vietnam, while at the same time increasing the risk of their being trafficked. This chapter, along with another chapter on migration by Graeme Hugo and Nguyen Thi Hong Xoan, focuses on the intersection of a variety of factors including, importantly, the deficit of women in the receiving country and poverty in the sending communities. Several chapters analyse how various genderbased practices and policies maintain and/or create new conditions that support rather than challenge the son-preference of male-dominated gender orders. Based on fieldwork in the People's Republic of China, anthropologist Laurel Bossen argues that there is a clear relationship between sonpreference and the rural land property system introduced as part of the economic reforms. Bossen concludes that the reform period revival of patrilineal control over village land rights in combination with the implementation of a national birth control policy has contributed to an extreme shortage of daughters in rural China because sons secure family wealth. Similarly, the chapter on Bangladesh by Nurul Alam, Jeroen Van Ginneken, and Alinda Bosch concludes that sons are valued for the potential wealth they bring to their parents and their extended families. These and other chapters emphasise that governments are confronted with major challenges in defining, promoting, and implementing gendersensitive policies. 
5 In the introduction, the editors lament the fact that they have not provided a unified theoretical framework for understanding the harsh practices of gender discrimination that underlie unbalanced sex ratios in Asia. What the book does provide, and what makes it worth reading, is a wealth of information on and analysis of the issue of skewed sex-ratios. The book aims to create an interest in the field and an awareness of the need for further research. It fulfils its intention by presenting a broad and varied selection of quantitative and qualitative studies that offer the reader many different perspectives on the significance of skewed sex-ratios for human development. 